\section{Dune(s): Fiction, history, and science on the Oregon coast}

\author{
Joana Gaspar de Freitas (iD
}

The Anthropocene Review

$1-19$

(C) The Author(s) 2021

(c) (i) (8)

Article reuse guidelines: sagepub.com/journals-permissions DOI: | $0.1 \mid$ |77/20530| 962 | |0568|4

journals.sagepub.com/home/anr

@SAGE

\begin{abstract}
What connects the sci-fi book Dune with coastal dunes and geoengineering? The answer lies in humans and their world-making activities. This paper proposes an innovative approach to coastal dunes as hybrid environments by analyzing the dunes stabilization programs developed on the US Pacific Coast. It looks into the shifting sands of the Oregon coast and how they influenced Frank Herbert to write his novel, why local communities and federal authorities were interested in fixing the moving dunes and how these works ended up having unexpected consequences. It explores how human features acting as forcing mechanisms on beach-dune systems caused changes that turned into controlling influences in their own right, creating new environments and concerns. The paper ends with a reflection on how fiction and the history of dunes can be used to critically think about the anthropocentric hubris of building futures by geoengineering the planet for environmental repair.
\end{abstract}

\title{
Keywords
}

Anthropocene, coastal management, environmental history, geoengineering, hybrid environments, sand dunes, science-fiction

\section{Introduction}

Dune, by Frank Herbert, is one of the most read and most decorated science fiction books. Dunes, on the other hand, are those large coastal features, located on the backbeach, formed by windblown sand trapped by vegetation (Elko et al., 2016: 8, 10). In Oregon, these two things, which share the same name, are linked by a story. A story that associates fiction, history, and science. A story that can be used to critically think about the Age of Humans regarding coastal management, the role of the environmental humanities, and the future of the planet.

Scientific understanding of coastal systems has experienced a great development since the last decades of the 20th century. Traditionally, the studies about dunes fall under the scope of natural 
sciences, which are mainly interested in analysing their location, formation, morphology, vegetation, management, and restoration. Numerous works have been produced about the physical, morphological, and ecological features of dunes, their current problems and the solutions found for their rehabilitation (e.g. Biel et al., 2017, 2019; Goudie et al., 1990; Hacker et al., 2012; Martínez and Psuty, 2008; Nordstrom, 2000, 2008; Packham and Willis, 1997). But, as global climate change and sea-level rise put pressure on these fragile ecosystems, more research is needed to support adaptive management strategies. These strategies are based in governance and planning centered in iterative learning about a system and making decisions according to that learning (Webb et al., 2017). To facilitate that type of decision-making better information is needed on the interaction between plant species, eolian transport, sedimentation processes, wave and current patterns, and the input of human activities, infrastructures, and development impacts. Elko et al. (2016: 2) stressed that there is an emerging necessity to incorporate the data of the social sciences and humanities into coastal management challenges. Indeed, few studies consider all together the economic, political, social, and cultural context of human uses and transformation of dunes, especially from a long-term perspective. There are some exceptions like the works of Freitas (2004), Van Dam (2010), Clarke and Rendell (2011, 2015), Sture (2012), Temple (2011), and Danaher (2005). However, the history of the interaction of people with dunes is still described in a limited way. This is because most historians do not think of dunes as historical subjects and most people do not realize that dunes have a history (Freitas, 2020).

After many centuries of human use and activities, dunes are no longer just a creation of the sea, sand, wind, and vegetation. They have become hybrid products, or as Tsing (2015:152) described about some landscapes, the result of "the overlapping world-making activities of many agents, human and not human." Therefore, other skills and tools can and should be used to address these socio-ecological-technical things (LeCain, 2017). The skills and tools used by social scientists and humanists to look at emotions, perceptions, beliefs, values, and experiences in order to see how people make meaning and how meaning changes and shapes the dunes and the world (Campbell, 2017: 21). This paper thus aims to fill the gap amid different disciplines by bridging and combining knowledge so as to offer a new approach to the complex setting of coastal dunes and their natural and cultural legacies. How may this be achieved? The answer, as Hodder (2012: 3) puts it, is by being subversive. By moving from the usual perspective of seeing the dunes from a geological, geomorphological, sedimentological, or ecological point of view, to proposing a multi-lens analysis on these subjects so that they can be perceived from different angles, thus revealing the imbricated ways in which society and things are co-entangled.

Millions have read Dune. Yet far fewer know the dunes and the stabilization works that are the inspiration of the book. To think about the Anthropocene, it is necessary to have new ways of telling stories. Stories that are simultaneously true and fabulous about unlikely combinations make people look for what has been ignored (Tsing, 2015: 7, 8, 21). This paper uses Dune to draw attention to dunes. This study takes the reader from dunes as fictional essences based on Herbert's vision of a hostile sand planet that can be improved by human will to the historical events of the Oregon dunes stabilization programs that inspired the novel and influence the present situation of that coast. The narrative summarizes the role of humans and nonhumans in land use changes and, describes the attempts to fix the drifting sands and the dunes transformation. It also points to their function in the dynamic of the beach-dune system and relevance as ecosystems, showing how the development of scientific knowledge and new cultural perceptions about coasts influenced the way dunes were viewed by the public. The paper develops the idea that combining different approaches allows one to connect facts, establish links, and associations between actors, motifs, forces, and changes over time. Therefore, revealing how values, legacies, setbacks, and unintended sideeffects influence the present and the possible futures to be made (White, 2018). Finally, an analogy 
is made comparing dune design and planet geoengineering, highlighting how interdisciplinarity is crucial to present other ways of thinking about the implications of the artificial worlds fabricated by humans.

\section{Fiction: Dune, the sand planet}

Dune by Frank Herbert has sold millions of copies since it was published in 1965. Winner of the Nebula and Hugo awards - the two most prestigious science fiction prizes - it is "perhaps the greatest novel" of the canon which inspired the well-known Star Wars and Game of Thrones franchises (Kunzru, 2015). The book is a "paradigmatic fantasy" (Kunzru, 2015) of the awakening of the environmental awareness in the United States, catalyzed by Rachel Carson's Silent Spring in 1962. Carson's work on the destructiveness of modern industry, through the misuse of chemical pesticides, became a bestseller and a political force in the political, social, and cultural context of the 1960s, connected to the revitalization of liberalism, the grass-roots activism of middle-class women, and the explosion of radicalism and countercultural protests (Rome, 2003). Silent Spring called into question the "scientific progress that defined the postwar American culture" says Mark Hamilton Lytle (McKie, 2012). The focus on the ecological pressure and scarcity of natural resources that pours from Dune's pages is an influence of that period (Herbert, 2003). Although Herbert's work was almost 30 years distant from the Dust Bowl crisis, the severe dust storms that affected the Great Plains in the 30s, its echoes still resonated then (Kratz, 2020). The event had a national significance, greatly impacting the American society, as it was the outcome of "culture operating in precisely the way it was supposed to" (Worster, 2004:4), prompting the fear of an ecological collapse. According to Kratz (2020), in Herbert's notes the ecologists working in the Siuslaw Conservation District shared their time between the dunes and the local farms for soil conservation planning. The Dust Bowl's legacy not only influenced their agricultural practices, but also a "cultural narrative that saw aridity and moving sands as a crisis to be solved." Dune takes on that idea about deserts as problems that could be fixed and made productive (Kratz, 2020). At the time, other eco-sci-fi novels, like Ursula K. Le Guin's The Dispossessed, also addressed the issue: the afforestation of the West Temaenian Littoral, in planet Anarres, a region evocatively called the Dust and described by Le Guin as "hills as pure of line and barren as any sand dune," was an attempt to "restore the fertility of that restless earth" (Le Guin, 1975: 37). These stories point to an instrumental approach to nature, with humans used as constructive ecological forces, but both also highlight the implications and risks of an economic system based in the intensive exploitation of resources, without regarding the needs of those who come after (Pak, 2016: 121-122; Herbert et al., 2005: 294-295). In the 1960s and 1970s, environmental changes were not as relevant as they are today, yet "books read differently as the world reforms itself around them" (Kunzru, 2015). Fifty-five years later, Herbert's novel is being analyzed in light of the increasing cultural awareness of global change.

The story takes place in a distant future, in a faraway galaxy, on Arrakis - a hostile planet also known as Dune. Covered by shifting sands and almost without water, it represents a challenge for those who try to live there. Its inhabitants have one main goal: to green their world, turning it into a self-sustaining system through a huge process of bioengineering the entire planet. The Fremen people, led by Pardot Kynes, a non-native plantologist, dreamed of remaking the arid sandy land by using human will as a constructive ecological and geological force to manipulate the landscape, and transform it into something new. The ecological vision beneath "the long-term terraformation of the planet" (Pak, 2016:119) was based in "gathering water, planting dunes," anchoring them with grass, bushes, and trees to create a forest cover. The Fremen would change Arrakis, "slowly but with certainty. . . to make it fit for human life," obtaining emancipation from scarcity, even if it took 300-500 years to achieve (Herbert, 2015: 311, 537). 
In the appendix, Herbert carefully explains the ecology of Dune. The planet looked an "overpowering barren land," where nothing could live or grow. But, as Pardot Kynes discovered, there had been open water in Arrakis once. It had disappeared due to the introduction of the sandtrout, a non-native species, a "water-stealer," that transformed the planet into a desert, by blocking off water in some pockets, as part of its metamorphosis to become a giant sandworm for whom water was poisonous. There was a life cycle connecting sandtrouts, sandworms, sand, and the spice. The excretion of the sandtrouts mixed with water, the pre-spice mass, exposed to sun, and air turned into spice or melange. Worms scatter the spice that fed the sand plankton. Plankton was food for the worms and the sand the product of their digestion. When worms died, they released sandtrouts into the sand. Melange was the one-crop of Arrakis, the most valuable commodity of the universe because of its multiple and relevant technological and cultural uses. Being the most important one its role in space navigation (Herbert, 2005). Pak (2016: 123) considers that spice mining and the wars connected to control it have a realworld correspondence in oil industry and its aggressive exploitative commerce.

For Pardot Kynes, Dune's hostile environment could be turned into paradise by manipulating the landscape, its climate and seasonal limits. This could be achieved by anchoring the dunes and using a successional planting scheme based, in the first stage, in poverty grass and other vegetation to mat the sand and prevent the winds from carrying it endlessly. Grasses put along the downwind face of the dunes would trap the sediments on the windward side, building a protective barrier that would allow plants to survive. When dunes were fixed, the deeper planting would begin using pigweeds, amaranths, scotch brooms, low lupines, shore pines, saguaros, wild alfalfa, incense bushes, and smoke trees. The next phase would be the introduction of animal life such as insects, birds, and small mammals necessary to open the soil and aerate it. Finally, at the last stage, would come the palms, the cotton, the melons, coffee, and medicinals. Pardot Kynes believed that, in time, this process would achieve the stature of a fully functioning ecosystem. He was also aware that these "changes [would] become controlling influences in their own right" and, at some point, they would have to be dealt with too (Herbert, 2015: 538-539, 296). Pak (2016:120) notes that the title of planetologist attributed to Kynes indicates a shift from the particularities of the local ecosystem to a focus on the global. The colonial conquest of Arrakis, the subjugation of indigenous populations, the exploitation of spice, and the transformation of the landscape greatly resembled the European settlement schemes imprinting their homelands' characteristics to the new territories.

Dune's fictional environment was inspired by reality. In July 1957, Frank Herbert chartered a small plane and flew over the vast shifting sands that are now the Oregon Dunes National Recreation Area. What he saw from the air drove him to write a novel about a harsh sand dune planet. Herbert's story was deeply influenced by that landscape and the efforts to stabilize the unsettled sands of the US Pacific Northwestern coast near the city of Florence. As the ecocritic scholar Katie Ritson (2019) observes, literary texts have the capability to incorporate both real and imagined landscapes, revealing how the human perception of space being a complex multi-layered experience imbues them with meaning. For Ritson these texts can be used to explore "all the paradoxes and contradictions inherent to the idea of the Anthropocene," because they "do not just capture a particular landscape for posterity, they meditate on it" bringing forward a "reflection on humanity's place in the world" (Ritson, 2019: 5-6, 14). For this reason, Dune is an amazing book which can serve as a vehicle to introduce and draw attention to the history and science of dunes, since it can be a creative tool to cast a light into dune building and the human attempts to forge their world.

\section{History: "They stopped the moving sand"}

Frank Herbert went to Florence to write a magazine article about the works that the US Department of Agriculture was implementing on that seashore (Figure 1). "They stopped the moving sand" is 


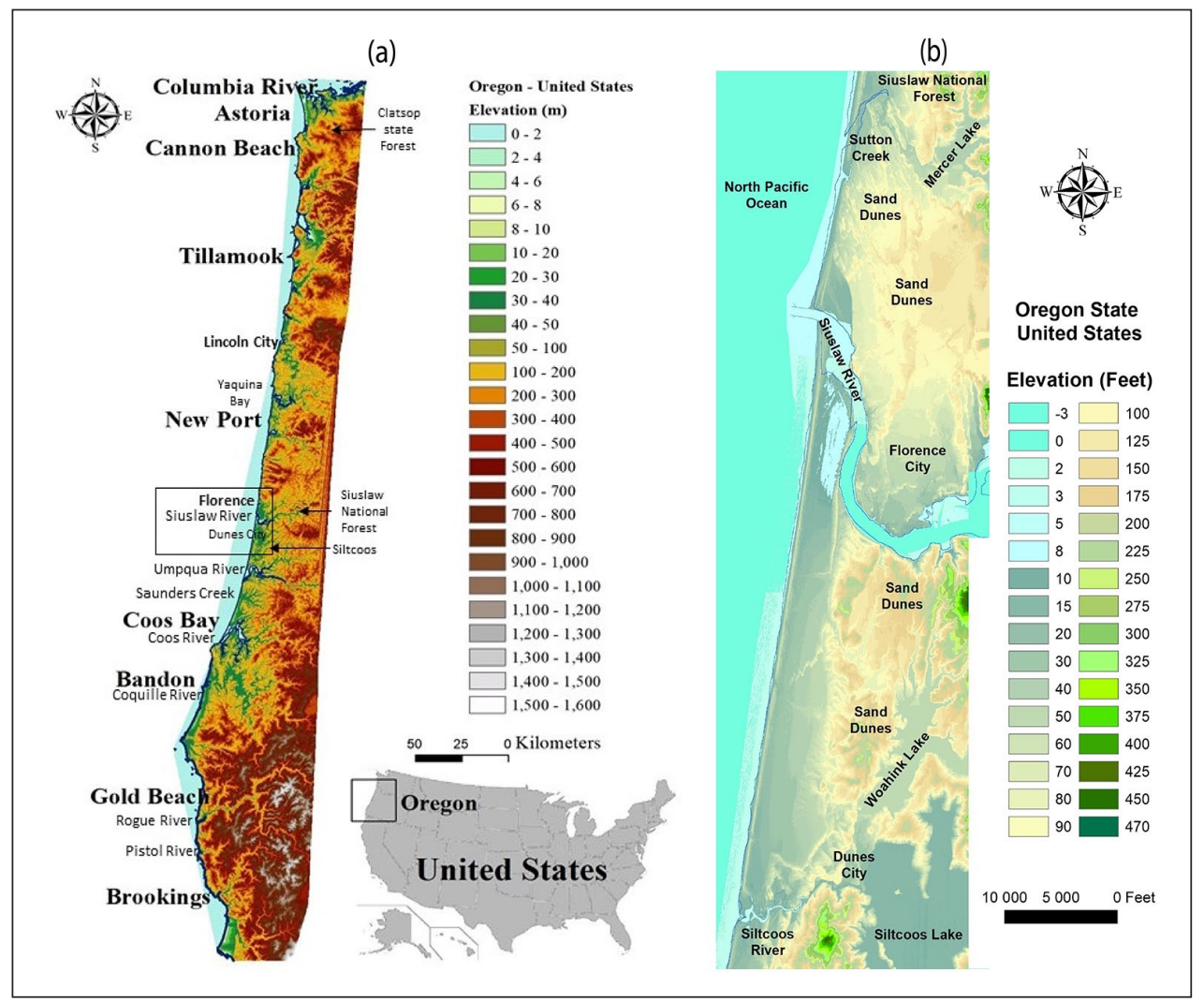

Figure I. (a) The Oregon coast (USA); (b) the coast near Florence and the sand dunes, Digital Elevation Model made by D.M.R. Sampath.

the title of his report on the issue (Herbert et al., 2005). In Florence, Herbert witnessed the efforts of the Soil Conservation Services to fix the drifting dunes which had become a threat by encroaching on houses, railway tracks, the 101 Highway, and the Siuslaw port. The Soil Conservation Services were installing fences and planting European beachgrass (Ammophila arenaria) to prevent the winds from carrying the sand and pushing the dunes further inland where they were a menace to human infrastructures. Herbert was fascinated by the idea and possibility of transforming wasteland into green areas. He referred to these works as "the first enduring answer to shifting sands in all history," praising it as an "unsung victory in the fight of men against dunes."

The article was not published in 1957 because Lurton Blassingame, his editor, considered that it needed more research and Herbert was already thinking about something else (Herbert, 2015). Blassingame was right; Herbert's report had no historical accuracy. The Department of Agriculture, for instance, was not responsible, as he wrote, for finding the solution to fix the moving dunes, nor was the Oregon coast the first place in the US where the strategy had been applied. The works carried out were inspired by practices tested for more than two centuries in several European countries. Also, the method used in Florence was known in the US, at least since the 19th century, as having been previously employed in Cape Cod and San Francisco (Lamb, 1898; The Forester, 1897; Westgate, 1904). To perceive what Herbert saw and fully understand the "battle of the sand dunes" (Herbert et al., 2005) being fought at the time, it is necessary to go deeper in history. 


\section{Solving the sand problem on the Oregon coast}

The descriptions of the Oregon coast in the 19th century presented it as largely mountainous and covered by heavy forests of cedars, pines and other conifers. In 1854 in the area of the Umpqua and the Siuslaw rivers, the sands thrown by the ocean extended inland for about 2-3 miles. Beyond them, there was a poor sandy soil, covered with trees of stunted growth (Dana, 1849; Scholfield, 1854). The local Tribes' stories mention channels blocked and bays filled in by sand, ancient sites abandoned because of advancing dunes. In the North of Umpqua estuary, archaeological remains reveal the existence of a lost village in a saltwater estuary, later cut off by the sand dunes and transformed into Tahkenitch lake (Whereat, 2010: 44, 26, 267). Until the mid-1800s, the land around the Siuslaw and Umpqua rivers' basins was home to the Siuslaw and Lower Umpqua people, who are now part of the Confederated Tribes of the Coos, Lower Umpqua, and Siuslaw Indians. They lived in these extensive estuaries and watersheds, using the resources of water bodies, forests, and floodplains, which included salmon, crabs, clams, wildlife, and edible plants. Wild ducks, for instance, were abundant in the lakes spotted throughout the dunes (Ctclusi, 2021; Thomas, 2010: 15; Whereat, 2010: 43). The Tribes steward their environments to suit their needs. By using fire for gathering, hunting, and harvesting, they influenced the extent and composition of forests and grasslands, possibly contributing to soil erosion and the increase of sediments reaching the coast by river transport (Komar, 1997; Robbins, 1997; Skinner, 1971). By the 1830s, diseases introduced by European traders and trappers started decimating the peoples of the Siuslaw and Umpqua valleys (Thomas, 2010: 17). In 1850, the Congress passed the Oregon Donation Land Act, which provided free land to those settled or settling in the region. The 1855 Treaty established the acquisition and settlement on the Confederated Tribes ancestral land. The treaty provided for compensation to the Tribes, but it was not ratified by Congress. In the following years, after the Rogue River Indian Wars of 1855-1856, the Coos Indians were rounded up and forced to march to Fort Umpqua, and later Coos and Umpqua were moved to the Alsea subagency in Yachats. Half of the Tribal members died of hunger, mistreatment, and disease at the reservation. In 1876, they were released to return to their homelands, to discover that their homes no longer existed, or go up north to the Siletz Reservation (Ctclusi, 2021; Whereat, 2010: 8-9). When the first Euro-American settlers arrived to the region they found the remnants of a vast and complex society significantly reduced in number (Thomas, 2010: 17). By 1880, many Euro-American families were settling up the Siuslaw river. They plowed the land, grazed cattle and cut timber, thus disturbing native plants and creating the ideal conditions for the proliferation of some exotic species. Riparian areas and hillsides were progressively cleared favoring soil erosion and silting up of streams (Robbins, 1997). Some of these eroded sediments may have reached the sea and contributed to the feeding of beaches and dunes. In 1882, some of the newcomers settled in the area that would become Florence, on the North bank of the Siuslaw not far from its mouth. According to Whereat (2010: 18), there was a Siuslaw village named Wai-tus, the "white mountain," probably a sand hill, identified as Old Town Florence. The place enjoyed from a suitable entrance to the river with its rich bottom lands, water and a healthful climate. In a few years, three fish-canning industries and a saw-mill explored the salmon teeming-rivers and the forest-covered mountains, sending cargoes of canned fish and lumber in vessels to San Francisco (Bancroft, 1888; Skinner, 1971; The Sunday Oregonian, 1912a). At a fast pace, the local subsistence economy was integrated into the trade circuit and dominated by distant markets. The building of the railroad lines through Oregon in the $1870 \mathrm{~s}-80$ s represented the extending of the empire network and the commodification of nature (Robbins, 1997).

Florence grew over the years in a region that was, and like all coastal areas still is, characterized by its dynamic features. At the end of the 19th century, on the North bank of the river, sand dunes between 50 and 150 feet high outspread for many miles, covered by a thick growth of small pines 
and ferns (Symons, 1891). Cooper (1958: 88) explains that "the great extent and continuity of [this] receptive shore backed by terrain favourable to dune migration give ample opportunity for development of materials and forces." According to him, the history of this region comprised episodes of intense dune advance, followed by periods of quiescence, repeated cycles of rejuvenation and stabilization, influenced by factors such as sand supply, climate, fire, and vegetation (Cooper, 1958). Cooper only analyzed the natural factors contributing to dune evolution, but human activities also had a major role in the transformation of this territory. For instance, the heavy forest coat that Euro-American settlers found when they arrived in the region had become, in 1908, the Siuslaw National Forest, by order of President Theodore Roosevelt. Many people lived then scattered around the reserve, lumbering, dairying, fishing, truck farming, fruit raising, and chittem bark peeling. A large part of it was, however, barren land since thousands of acres of trees had been consumed by fires and land clearance, leaving hills and ridges unclothed. Moreover, sand "crawling far in from the shore, ha[d] destroyed many square miles of vegetation." The phenomena were possibly connected, as agriculture, deforestation and mining had enhanced hinterland soil erosion providing more sediment to the rivers (Robbins, 1997) thereby increasing the amount of sand that reached the coast. Replanting was then the major challenge imposed to the foresters working on the reclamation of mountains, marshes, and sands (The Sunday Oregonian, 1912b). The construction of the Siuslaw jetties (between 1891 and 1915) was also responsible for some human induced shoreline change patterns, such as accretion on both the northern and southern sides of the structures (Ruggiero et al., 2012).

The problem of the drifting dunes was not exclusive to the Siuslaw River area. In fact, it affected other localities along the Pacific Northwest coast and the banks of the Columbia River (Figure 2) where the sand was covering to the railway tracks (East Oregonian, 1901; Robbins, 1997; The Daily Journal, 1902). In Clatsop Plains, the loose sand had deposited "on the grazing lands of farmers with the result that many fertile acres became buried" (The Sunday Oregonian, 1913). The causes had long been identified: excessive pasturage had destroyed the wild vegetation that covered the sea ridges before the arrival of the Non-Native settlers thus turning the sand free (The Sunday Oregonian, 1913). The solution was also known: keep the cattle out of the dunes so that native plants could spread over again. But, there was also the idea that more could be done by following the experiments made at the Golden Gate Park (Tri-Weekly Astoria, 1874). Dune reclamation in San Francisco in 1869 seems to have been the first try out of its kind on the Northern Pacific Coast. A strip of sand hills lying between the city and the bay had been seeded with European beachgrass, which had grown for 2 years, holding the ground for the second phase which involved the planting of tree species like the Monterey pine and the Monterey cypress. The reclaimed area had been converted into a large city park, thereby increasing the economic value of the land (Lamb, 1898).

On the Clatsop Plains, experiments were carried out to find the right sand-binding plants to "stop the sand from drifting and thus convert what [were then] barren and unattractive hills into grassy downs, easy of access, picturesque and slightly" (Cowles, 1899; The Morning Oregonian, 1900). In the early-20th century, the town of Clatsop had a board of elected trustees with the mission, among others, to provide against the further encroachment of the sands upon the agricultural lands and to reclaim the dunes (The Sunday Oregonian, 1913). Putting the solution into practice, however, would take decades. In the 1930s, the dunes were still a problem in the region, menacing forts, roads, and private property, jeopardizing also the "ocean-going commerce moving in and out of the entrance to the Columbia River" (Bennett, 1942). In fact, the situation was getting worse, with the destruction of the natural cover by overgrazing, fire and, with a rapidly increasing population that built infrastructures unsuitable for the local ecosystem. The construction of jetties (the south one was built in 1885) at the mouth of the Columbia had changed the pattern of sediment distribution on the immediately adjacent beaches, increasing the amount of sand available to be 


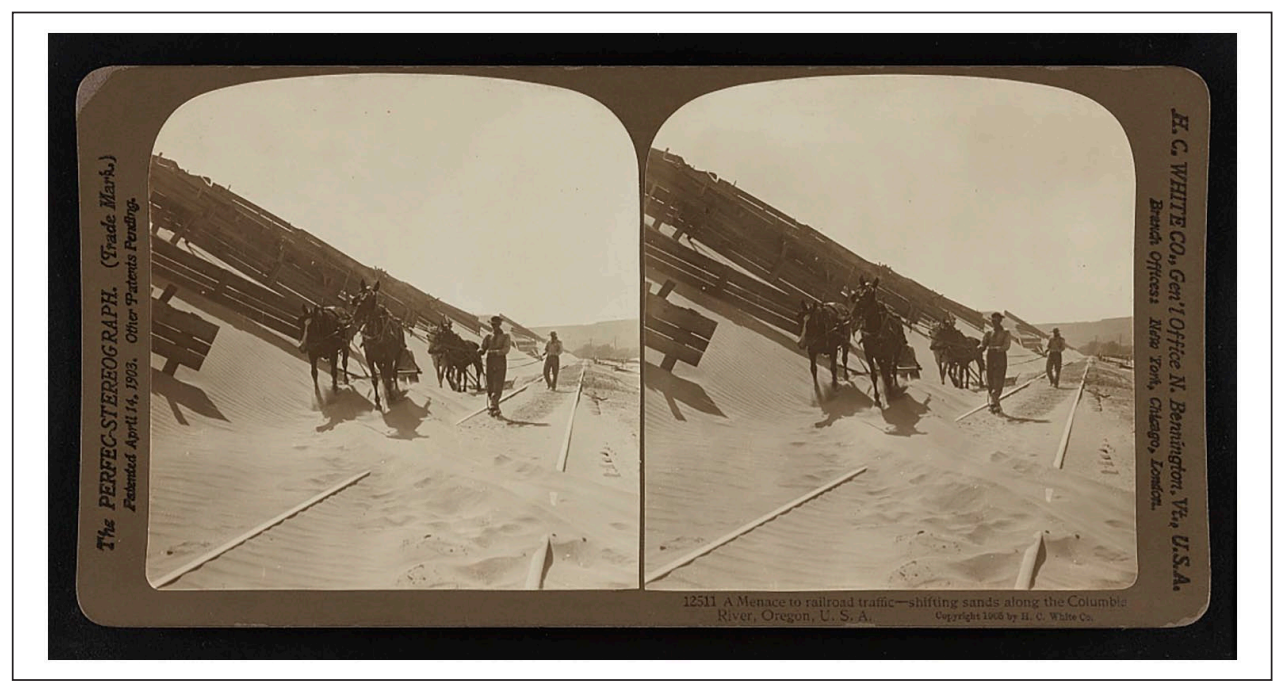

Figure 2. A menace to railroad traffic: the shifting sands along the Columbia River, Oregon, 1905. Source: Library of Congress and Photographs Division Washington, D.C. https://www.loc.gov/pictures/ item/2018651830/.

carried inland by winds (Kaminsky et al., 2010). Therefore, in 1935 the Soil Conservation Service began the task of stabilizing those shifting dunes. The initial work - the establishment of a foredune, sand-stilling with grasses, and permanent stabilization with herbaceous and wood vegetation-lasted until 1941 (USDA Soil Conservation Service and the Oregon Coastal Conservation and Development Commission, 1975). Around three thousand acres of active dunes were systematically fixed (Figure 3). The success of the Warrenton Dune Demonstration Project, in Clatsop County, would provide both the technical information and the incentive to apply artificial dune stabilization as a management tool in the West Coast in the years that followed (Green, 1965; Reckendorf et al., 1985; USDA Soil Conservation Service and the Oregon Coastal Conservation and Development Commission, 1975).

Florence and the Siuslaw region were, like Clatsop, some of the first coastal areas of Oregon where dune stabilization was attempted. In 1913, a local newspaper highlighted how the forester responsible for the Siuslaw Forest was undertaking efforts to plant willow cuttings in the dunes, with the purpose of making a wind break to protect the pine seeds used in the afforestation of those sands (The Coos Bay Times, 1913; The Morning Oregonian, 1913). According to a later report, between 1910 and 1916, 47 acres of dunes were planted between Florence and Coos Bay under the coordination of the US Forest Services. These used European beachgrass, shrubs, and trees in the process. In 1936, around forty acres of dunes near Mercer Lake Recreation Camp just north of Florence were planted with beachgrass to stop the encroachment of the forest and camp (McLaughlin and Brown, 1942). Botanist Diantha Green (1965) mentions some interventions at Sutton Lake, Siltcoos Recreation Area, and Saunders Lake in 1935 and 1937. This was not enough, though, as farmers and business people kept complaining about sand invading agricultural and forestry land and impairing navigation on the Siuslaw river (Heppner Gazette Times, 1941). In fact, between Florence and Coos Bay, "huge dunes [were] approaching within a few yards of the Coast Highway." Here and in other areas of the Oregon coast, railroads were continually menaced by the shifting sands, which at several other points advanced "onto forests, overriding valuable pastures and croplands, obliterating lakes, threatening military reserves, filling stream channels, and endangering 


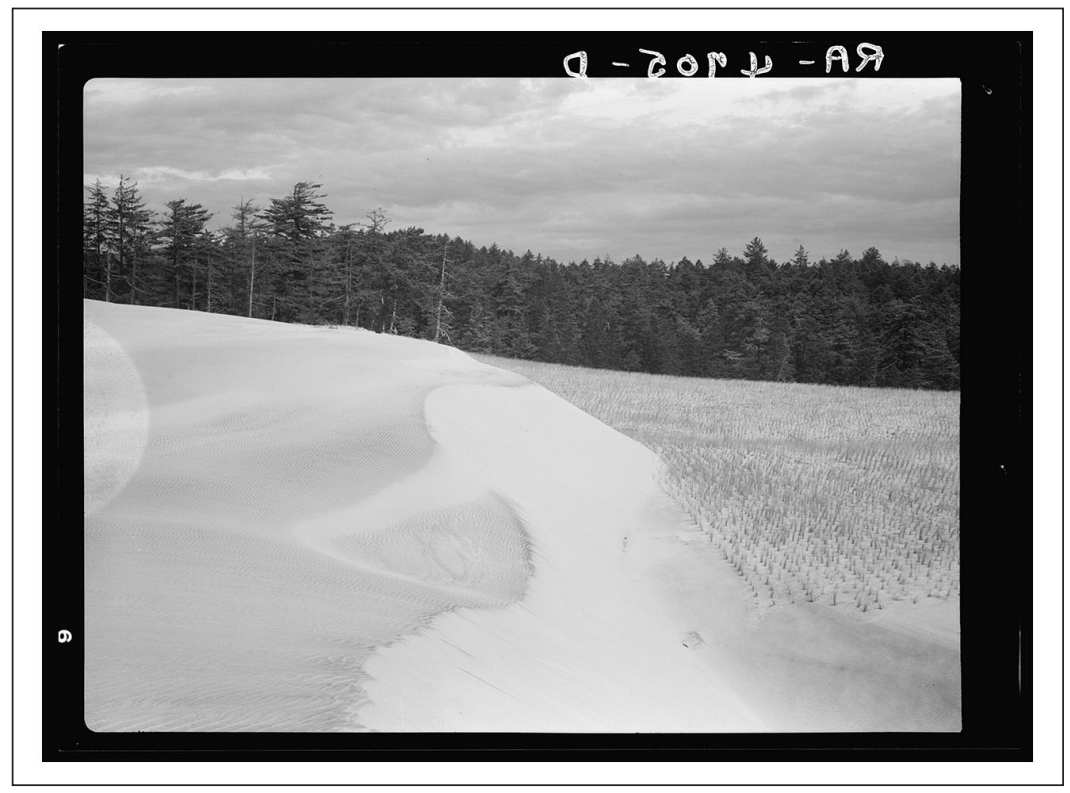

Figure 3. Sand fixation on the Oregon coast through the planting of Holland Grass, 1936.

Source: Library of Congress, Prints and Photographs Division, FSA/OWI Collection (Reproduction number: LC-USF34004705-D (b\&w film nitrate neg.) LC-DIG-fsa-8b27856) https://www.loc.gov/pictures/item/2017760706/.

resort property" (McLaughlin and Brown, 1942: 2). According to Cooper (1958: 114), between 1945 and 1951, dunes moved inland, north and south of the Siuslaw River at a rate of 5 feet per year.

Beginning in 1948, an extensive planting program between the Siltcoos and the Siuslaw Rivers was carried out by the US Forest Service and the Bureau of Land Management in cooperation with the Soil Conservation Service. Throughout the $50 \mathrm{~s}-60 \mathrm{~s}$, they were able to stabilize part of the dunes in the region: 300 acres south of the Siuslaw and 400 acres at the Siltcoos Recreation Area (Green, 1965) These were probably the very works that Frank Herbert saw in 1957 and the ones he mentioned in "They Stopped the Moving Sand" in saying: "The group in Oregon solved the many problems that go into taming the sands and [. . .] their solution works make an exciting story" (Herbert et al., 2005). He found them so thrilling that they become a key-piece in his novel, being adopted as the strategy used by Pardot Kynes to green the Fremen hostile sand world and set them free from scarcity. In Dune ecology, Herbert reproduced the mechanisms by which beachgrasses stabilize sand based on the ecological successional theory used by the Forest Services with the purpose of building a self-perpetuating ecosystem. What his readers might think is fiction - the idea of stabilizing dunes with grasses - is in fact a proven-effective method applied worldwide, even today.

\section{Changing landscapes, changing values}

The analysis of aerial photographs from several decades of the Siuslaw area allowed scientists to realize that this landscape was changing due to human intervention as intended. In 1941, a series of photos taken from Florence to Tahkenitch Creek showed no vegetation on the dunes west of the forest's edge near Highway 101, except for some patches near Clearwox Lake and along the 
Siltcoos and Tahkenitch waterbodies. Two years later, between the mouth of the Siuslaw and the east part of Clearwox Lake, clumps of European beachgrass were growing on both sides of the river mouth, extending south along the beach ridge (Pinto et al., 1972). Ammophila arenaria was introduced in Oregon during the first experiments on sand-binding plants at end of the 19th century. It became part of the initial stage of the dune stabilization programs and then spread naturally (Hitchcock and Chase, 1950; Hitchcock et al., 1969; Pinto et al., 1972). The European beachgrass captures the windblown sand and, in turn, its growth is stimulated by sand deposition. This creates a positive feedback loop between the grasses and the sand deposition favoring the building of tall stable dunes (Hacker et al., 2012; Zarnetske et al., 2015). This contributed to the formation of a foredune that acted as a barrier cutting the sand's continuous supply from the beach to the landward side. The lack of sand resulted in the wind eroding the back dune plain to the water table, creating a deflation plain that extended eastward. Before the introduction of the Ammophila arenaria, foredunes and the deflation plains did not exist on the Oregon coast. This new belt of low wetlands was rapidly colonized by pioneering plant species like rushes, sedges and willows, forming dense shrub, and later forest communities (Forest Service, 1979; USDA Soil Conservation Service and the Oregon Coastal Conservation and Development Commission, 1975; Wiedemann and Pickart, 2008). The comparison of aerial photographs of the south spit of the Siuslaw River and Goose Pasture, taken between 1941 and 1971, shows that the width of the deflation plain increased significantly during this period (Pinto et al., 1972).

Cooper (1958: 112) was right when he wrote that the rapid spread of the European beachgrass would "have a profound influence in shaping the future of dunes." The exotic species overtook the native plants and throughout the years altered local landscapes and ecosystems. A territory before flowing by wind-driven sediments was transformed into permanent wetlands and woodlands. European beachgrass effectively stopped the moving sand. More, it stabilized the sandy coastline by rapidly spreading outside the areas where it was originally planted. This is now being described as an unintended consequence of the previous works or their unforeseen result (Oregon Dunes Restoration Collaborative, 2018). However, one may question this observation since the purpose of dune stabilization was precisely to fix and turn them into green areas (Figure 4). What must be pointed out is that in the course of a century, not only did the landscape change, but also the perceptions, values and knowledge as well.

In the 1940s, the work of taming the dunes had become a process based on proven principles. The first experiments based in trial-and-error attempts established the procedures that were thereafter reproduced in other places. A detailed report made then (McLaughlin and Brown, 1942) described the materials and methods to use and explained, step by step, what should be done to effectively improve the sand drifting areas. Dunes needed to be controlled, that was the main trend at the time. Actively moving dunes were thought to be caused by "man's intervention," so it was "his duty" to maintain their protective vegetation cover and prevent that (McLaughlin and Brown, 1942). This perception would, however, change over the years. As the recreational use of beaches increased, scientific knowledge about the beach-dune systems developed and the decrease in sand supply to the shore brought new challenges to coastal management. The creation of the Oregon Dunes National Recreation Area (ODNRA) is an example that ideas about the coast were shifting.

Public Law 92-260 (1972), created ODNRA "for the public outdoor recreation use and enjoyment of certain ocean shorelines and dunes, forested areas (. . .) and the conservation of scenic, scientific, historical and other values". The social, political and environmental conditions that made this possible are connected to post-war development of the Oregon coast and the counterbalance efforts to protect it, as part of the broader environmental political agenda set in the 60s (Rome, 2003). Oregon was the first State to make all its beaches public by assuring public access in 1913 (Deur, 2016) and, in 1967, to allow public ownership of land from the water up to sixteen vertical 


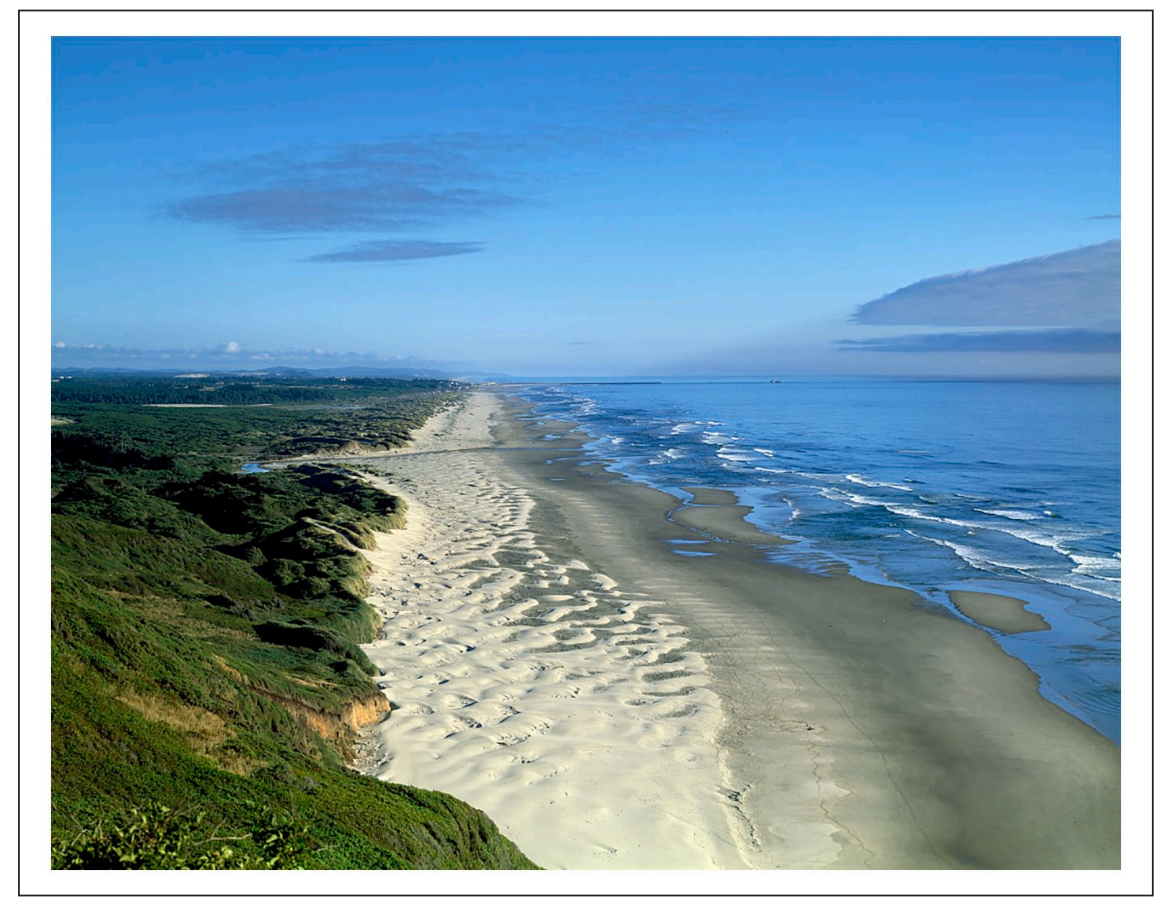

Figure 4. Oregon dunes along the Pacific Ocean, by Carol M. Highsmith, 1980.

Source: Photographs in the Carol M. Highsmith Archive, Library of Congress, Prints and Photographs Division (Reproduction number: LC-DIG-highsm-I3803 (digital file from original) LC-HS503-2888 (color film transparency)) https://www.loc.gov/item/2011631997/.

feet above the average low tide mark (the Oregon Beach Bill). The creation of ODNRA was also linked to the new aesthetic paradigm on outdoor recreation and appraisal of wild places expressed in the Wilderness Act - the conservation bill passed in 1964 to protect the most pristine landscapes for future generations. In 1979, ODNRA included 32,150 acres and around 38 miles of beaches located between Florence and North Bend. Approximately 1/3 of the area was active open sand dunes, some 300 feet above sea level and 5000 feet wide. There were also older naturally vegetated rolling dunes. The remaining area included the timbered foothills of the Coast Range (Forest Service, 1979).

In the 1970 s, the active open dunes still represented a danger to the pastureland, cropland, roads, railways, residential, commercial, and industrial property, but they were also seen as having "a tremendous aesthetic and recreational importance" (USDA Soil Conservation Service and the Oregon Coastal Conservation and Development Commission, 1975: 27). Stabilization projects were not abandoned, as they were still needed to cope with the problems caused by the moving dunes. They were, however, limited to specific places and to the essential to reduce their impacts (Forest Service, 1979: 36, 61). The 70s also marked the beginning of a new trend that explored the possibility of removing the foredunes and the European beachgrass to allow the fresh sand from the beach to continue feeding the inland dunes (Forest Service, 1979; Pinto et al., 1972; USDA Soil Conservation Service and the Oregon Coastal Conservation and Development Commission, 1975). During the hearings to establish the plans for the management of ODNRA, "the public voiced their desire for open dune areas left in their natural state for recreational and scientific purposes" 
(Carlson et al., 1991). People wanted to visit, hike, ride buggies, live, and feel the open dunes (Oregon Coastal Zone Management Association, 1979). Cultural perception about the dunes had clearly changed.

\section{Science: Designing dunes, creating hybrid landscapes}

In the last decades of the 20th century, coastal science shed new light on the role of dunes and beaches "as part of a linked sediment exchange system" along the nearshore, in connection with the watersheds (e.g. Elko et al., 2016; Zarnetske et al., 2015). It is now known that dunes are multifunctional ecosystems providing essential goods and services: they offer habitat for unique plants and animals, filter pollutants, purify groundwater, offer raw-materials (sand), and support many recreational (and therefore economic and social) uses (Nordstrom, 2008). They also have one function that has been highly valued: the safeguarding of the human built environment. Together with beaches, "dunes protect low-lying, developed coastal areas from elevated water levels associated with coastal storms," and are "recognized as a cost-effective method" of securing the property and assets of those living by the ocean. As such, they have been included as a "design feature in shoreprotection projects," a building with nature solution to enhance the resilience of natural systems. The reason for the present interest in dunes has to do with the challenges of current times. The increasing human pressure on the shorelines and the risk of coastal hazards due to the expected increased storminess, "accentuate the need to find ways to maximize the resource value of dunes" in absorbing storm impact (Elko et al., 2016).

The excessive exploitation of sand as a raw material, the urban sprawl along the seashore, the industrial and port area growth associated with the environmental changes of the last century, have however contributed to the degradation of the dunes' ecosystems, affecting their capacity as bufferareas by reducing their dynamic and biological functions (Martínez et al., 2008b). For this reason, the restoration and conservation of dunes have become a priority for coastal management in many countries (e.g. the USA and the European Union) that have adopted legal measures, raised funds, and got the support of public opinion to carry out those tasks. Around the world, dunes are being designed and built, or helped to recover after extreme events to ensure shore-protection. This is done using sand beach nourishment, bulldozers to fast pile the sediments or fences, and vegetation to trap the sand (Nordstrom, 2000).

Coastal protection is a valued service, but it is not the only one. "Nature conservation policies have changed from a focus on rare and endangered species to biotic and abiotic processes and landscape functioning," which means maintaining the natural dynamics of the ecosystems. Allowing a certain degree of dune mobility is understood as part of a holistic management interested in increasing its resilience to a future change in conditions (Martínez et al., 2008a). Following this current, one of the present concerns regarding the ODNR has to do with the spread of the European beachgrass and its effect on the unique ecosystem of those sands, threatening native plants and the animals that depend on them. Ammophila arenaria mats cover the sand preventing other vegetation from gaining a foothold and, by catching the wind blown-sand, they stop the seasonal movements that has characterized these dunes for so long. The landscape is changing and to prevent this, the Oregon Dunes Restoration Collaborative, a group of stakeholders, was created, in 2014, to coordinate the dune restoration efforts. Its purpose is to bring back the moving dunes and their wildlife by eliminating invasive species and re-establishing the features of an active dune ecosystem. Just like it was to green them a century before, restoring open sand dunes is considered to be a challenge: a complex, expensive, and long-term task (Oregon Dunes Restoration Collaborative, 2018; Wiedemann and Pickart, 2008). This new strategy, however, raises many doubts since "it still not known how much mobility can be integrated into dunes built for shore 
protection without sacrificing integrity as a barrier against overwash" (Elko et al., 2016). Vegetation is important to keep dune stability and to have dunes, its sand-trap effect is particularly relevant in beaches where the sand supply rate is low (Zarnetske et al., 2015). The present state and concerns about the Pacific Northwestern coast are likely to alter in the future as new forcing mechanisms put pressure on the system. In the restlessness of coastal environments, indeterminacy is surely key: for instance, in 2012, it was discovered, on the Oregon and Washington shores, a novel hybrid formed between two non-native dune-building beachgrasses, Ammophila arenaria and Ammophila breviligulata. The effects of the possible spread of this plant on dune morphology and biodiversity conservation is still unknown (Mostow et al., 2021).

In analyzing the different views on dune management, it is interesting to note that the rhetoric that justifies them is quite similar. Restoring the Oregon dunes is seen as a decade-long effort, but the people involved hope to put a halt to European beachgrass, so their grandchildren can enjoy the place as it exists now (Oregon Dunes Restoration Collaborative, 2018). Frank Herbert imagined the Fremen decided to stop the moving sands, even if "our generation will not see it, nor our children nor our children's children" (Herbert, 2015: 343, 312). Herbert was reproducing the missionbased commitment that he found in Florence when the active dunes were considered destructive, overriding, obliterating, burying, threatening, and endangering property, unless immediately controlled (McLaughlin and Brown, 1942). In 1957, those responsible for the stabilization works were thinking about the future of the next generations, safeguarding their interests by preventing dune encroachment. Nowadays, those who defend the maintenance of the foredune as a protection barrier by keeping the European beachgrass, are equally concerned about the days to come, bearing in mind climate uncertainty, the need to set probable scenarios, and choices to be made on the available paths. While there are so many doubts about "where th[is] world-in-process is going" (Tsing, 2015: 264), creating human-assisted active dunes or engineering sand barriers against sea hazards have become widely used as an adaptation measure. One thing is sure though, as Herbert wrote concerning the environmental interventions in Dune, these changes too will become controlling influences on their own, they will have unforeseen impacts and will have to be dealt with. . . later.

\section{Dunes and planets: The unruliness of things}

Frank Herbert's idea of engineering an entire planet by manipulating its landscape and climate to create a better world for humans is considered sci-fi. But, this is what humans have been doing for millennia-acting as ecological and geological forces with the purpose of controlling their environments, exempting themselves from the shortage of resources, and searching for the freedom and abundance that some call progress and growth. Herbert found in the Oregon dune stabilization program an example of a long-term project to harness nature and make it fit for humans. He thought the idea of transforming barren land into green forests to be so amazing that he incorporated it in this novel as the promise that drove the Arrakis "inhabitants' efforts toward the shaping of a new future" for the generations to come (Pak, 2016: 118). This is also the basis that guides the present framing of engineering the Earth as a way to address climate change.

Geoengineering is a highly controversial issue. The concept has been applied to the "possibility of engineering the earth's climate system by large-scale manipulation of global energy balance" (Apps et al., 2011: 333). Many strategies have been proposed, such as releasing sulphate particles into the stratosphere to mimicking volcanic eruptions and deflect solar radiation and, seeding the oceans with iron to stimulate the growth of algae and increase $\mathrm{CO}_{2}$ absorption (Pearce, 2019). The main question, like the IPCC (2014) report states, is that knowledge about the effects of the adoption of these technologies and processes is highly preliminary. There are still many unanswered questions related to risks, costs, governance, and ethical implications (IPCC, 2014). Recently, an 
article in Nature mentioned geoengineering as "outlandish and unsettling," invoking "technologies that are redolent of science fiction." However, its authors concluded that, "as things stand, politicians will face this dismal dilemma within a couple of decades" (Pearce, 2019; Rahman et al., 2018). Engineering dunes is only a small-scale project when compared to the remaking of a planet, but as Herbert used it to build his terraforming story, the example of dune intervention in the Oregon coast can be useful to reflect on one of the biggest challenges of the Anthropocene: engineering the Earth to avoid the worst consequences of human-induced global climate change.

Tsing (2015: 171) considers that "history-making extends [well] beyond what humans do." The history of dunes allows one to see that they are hybrid entities, shaped by many different forces, beings, and convergences - sea, wind, sand, vegetation, animals, human bodies, perceptions, values, knowledge, policies, fences, and bulldozers. Dunes can be framed by humans, but as they grow, move, transform, or erode, they have a direct impact on humans' lives. Both humans and dunes affect the plots of each other's stories. The entanglement of humans and things, says Ian Hodder, signifies that humans' interference with natural systems bond them to sustain some continuous form of care, regulation or discipline to maintain those systems so that they may produce, work or behave as they are supposed to. And, since things have different temporal rhythms and scales, the labor and costs invested in carrying out the work, as well as the processes and routines of keeping the world, trap humans in long-term actions, and impacts that cross generations (Hodder, 2012: 69, 85, 100101). For instance, the birth of Florence at the end of the 19th century set the stage for the first problems with the drifting sands. Those were caused by deforestation, land clearance, overgrazing, and the implantation of infrastructures in a very dynamic environment. Fixing the dunes was the direction taken then. This bound the US Forest and the Agriculture Services, as well as the local community, to the commitment of planting the sand for over 50 years. This obligation goes even further if one takes into account that the task of caring for the dunes is still an open issue considering the various views, values, and complications associated with their present situation.

The connection between people and things though is not just based in the materialities or the actions of building and domesticating. There are also the purposes and intentions embedded in the "generalized systems of discourse and value" (Hodder, 2012: 96) that represent the web of meaning of a certain society or culture at a specific moment. As the symbolic, cultural, emotional, political, economic, and social discourses change over the years, they introduce new significations to the world. Moreover, societies are not coherent units; different models and solutions can thrive in the same period, coexisting with or antagonizing each other. This is all quite clear in the case of Oregon and other coasts: since the days of the first dunes stabilization programs, perceptions, ideas, values, and policies have shifted. Fixing drifting dunes is no longer a generalized solution, but a local specific procedure. The battle against the dunes was replaced by the will to fight to keep them free, wild and open, or as designed shore-protections. Nevertheless, it is still necessary to deal with the consequences of the previous options and, at the same time, cope with the new problems.

Entanglements, stresses Hodder, are provisional, worked out in practice, as humans continuously change their minds and things have a life of their own. History shows how often human attempts to rationalize, standardize, or fix the world, based on their "self-confidence about scientific and technical progress" (Scott, 1998: 4), can easily get out of control because of "the unpredictable unruliness of things" (Hodder, 2012: 110-111). The open-endedness of connections, the multiplicity of links between webs, the embroiled responses, and adjustments of both humans and things have led to many surprises, both good or bad, but frequently unforeseen, unexpected, and unintended. Dunes are just microcosms compared with the complexity of the planetary system. Their history, though, full of pitfalls, and rumbling and tumbling demonstrate how attempts to master ecosystems bind humans to what appears to be an endless responsibility, as they become trapped in the need to fix the 
setbacks of their earlier well-intended decisions. The introduction of the European beachgrass on the US Pacific coast and the novel hybrid plant discovered recently are fine examples of that. Likewise, the Dune trilogy reveals the implications of shortening the way to produce rapid changes to the global environment, as it moves from seeing terraforming as a "positive physical and socio-cultural transformative force to terraforming as a problematic symbol of an ecopolitical dictatorship and deterritorialisation," (Pak, 2016: 124) since practices are no longer rooted in place and local voices are disregarded. Extrapolating from dunes to planets, from fiction and history to science, how not to fear the full consequences of global climate repairing for future generations and the world to come? Especially if that means imposing one-size-fits-all solutions-like using Ammophila arenaria as a sand-binder in the past - to address environmental problems, based in decisions of world leaders (pressed by conflicting interests), acting as the new Muad'dibs of planet Earth.

The story of the dunes that inspired Dune and Herbert's fiction on terraforming offer a different way of reflecting about building futures. Humans must be able to think of the possibilities ahead and the available paths, without forgetting, however, the limits and the uncertain outcome of their plans (White, 2018). Humans can be makers of many things, but they are also the "products of a material world that is constantly creating and recreating them" (LeCain, 2015: 23). This should compel humans to a humble and cautious respect for a "radically altered, hybrid and restless planet" (White, 2018), which they do not control.

\section{Acknowledgements}

The idea for writing this piece came from a discussion with Ryan Tucker Jones about the sand dunes of Oregon and Frank Herbert's masterpiece. He also introduced the author to Ursula K. Le Guin's books and read the first draft. Thank you, Ryan, for that! The author is also very grateful to the anonymous referees of this paper, who provided relevant information and suggestions to improve it. Their comments were precious to realize what was missing or less clear and what needed to be added.

\section{Funding}

The author disclosed receipt of the following financial support for the research, authorship, and/or publication of this article: This paper is an output of project DUNES. Sea, Sand, People, funded by the European Research Council (ERC) under the European Union's Horizon 2020 Research and Innovation Programme (Grant Agreement no. 802918).

\section{ORCID iD}

Joana Gaspar de Freitas (iD https://orcid.org/0000-0002-1313-8290

\section{References}

Apps M, Cerri C, Fujimori T et al. (2011) Technological and economic potential of options to enhance, maintain, and manage biological carbon reservoirs and geo-engineering. Summary for policymakers. Climate change 2001: Mitigation. A report of the group III of the Intergovernmental Panel on Climate Change. Available at: https://www.ipcc.ch/report/ar3/wg3/chapter-4-technological-and-economic-potential-ofoptions-to-enhance-maintain-and-manage-biological-carbon-reservoirs-and-geo-engineering/ (accessed 26 July 2021).

Bancroft HH (1888) History of Oregon. San Francisco, CA: The History Company Publishers.

Bennett HH (1942) Foreword. In: McLaughlin W and Brown R (eds) Controlling Coastal Sand Dunes in the Pacific Northwest. Washington, DC: US Department of Agriculture. Available at: https://naldc.nal.usda. gov/download/CAT92981355/PDF (accessed 19 November 2021).

Biel RG, Hacker SD, Ruggiero P et al. (2017) Coastal protection and conservation on sandy beaches and dunes: Context-dependent tradeoffs in ecosystem service supply. Ecosphere 8(4): e01791. 
Biel RG, Hacker SD and Ruggiero P (2019) Elucidating coastal foredune ecomorphodynamics in the U.S. Pacific Northwest via Bayesian networks. Journal of Geophysical Research Earth Surface 124: 19191938.

Campbell S (2017) Making climate change our job. In: Siperstein S, Hall S and LeMenager S (eds) Teaching Climate Change in the Humanities. London and New York, NY: Routledge, pp. 17-23.

Carlson J, Reckendorf F and Ternyik W (1991) Stabilizing coastal sand dunes in the Pacific Northwest. Report, Soil Conservation Service, US Department of Agriculture.

Clarke ML and Rendell HM (2011) Atlantic storminess and historical sand drift in western Europe: Implications for future management of coastal dunes. Journal of Coastal Conservation 15: 227-236.

Clarke ML and Rendell HM (2015) This restless enemy of all fertility: Exploring paradigms of coastal dune management in Western Europe over the last 700 Years. Transactions of the Institute of British Geographers 40: 414-429.

Cooper WS (1958) Coastal Sand Dunes of Oregon and Washington. New York, NY: Geological Society of America.

Cowles HC (1899) The Ecological Relations of the Vegetation on the Sand Dunes of Lake Michigan. Chicago, IL: The University of Chicago Press.

Ctclusi (2021) Confederated tribes of Coos, Lower Umpqua and Siuslaw Indians. Available at: https:/ctclusi. org/history/ (accessed 30 July 2021).

Danaher M (2005) Reconciling foreshore development and dune erosion on three Queensland beaches: An historical perspective. Environment and History 11: 447-474.

Dana JD (1849) United States Exploring Expedition, During the Years 1838, 1839, 1840, 1841, 1842, Under the Command of Charles Wilkes, USN, X. Philadelphia, PA: C. Sherman.

Deur D (2016) Empires of the Turning Tide. A History of Lewis and Clark National Historical Park and the Columbia-Pacific Region. National Park Service, US Department of the Interior.

East Oregonian (1901) The chief tree planter examines shifting sand along Columbia, 10 October.

Elko N, Brodie K, Stockdon H et al. (2016) Dune management challenges on developed coasts. Shore \& Beach 84: 1-14.

Forest Service (1979) Final environmental statement Oregon Dunes national recreation area. Management plan. Report, US Department of Agriculture, Pacific Northwest Region.

Freitas JG (2004) A Política Florestal nos Últimos Dois Séculos: Estudo sobre as intervenções nas dunas do litoral português. In: Tavares AA, Tavares MJ and Cardoso JL (eds) Evolução Geohistórica do Litoral Português Fenómenos Correlativos. Geologia, História, Arqueologia e Climatologia. Lisboa: Universidade Aberta, pp.599-626.

Freitas JG (2020) Making a case for an environmental history of dunes. Anthropocenes - Human, Inhuman, Posthuman 1: 1-5.

Goudie AS, Nordstrom K, Psuty N et al. (1990) Coastal Dunes: Form and Process. Chichester: Wiley.

Green DL (1965) Developmental history of European beachgrass (Ammophila Arenaria (L.) link) plantings on the Oregon coastal sand dunes. In: Diss M (ed.) Oregon State University. Available at: https:// ir.library.oregonstate.edu/concern/graduate_thesis_or_dissertations/4q77fv1 (accessed 19 November 2019).

Hacker SD, Zarnetske P, Seabloom E et al. (2012) Subtle differences in two non-native congeneric beach grasses significantly affect their colonization, spread, and impact. Oikos 121:138-148.

Heppner Gazette Times (1941) Landowners urge organization of soil districts, 4 September.

Herbert B (2003) Dreamer of Dune: The Biography of Frank Herbert. New York, NY: A Tom Doherty Associates Book.

Herbert F (2015) Dune. London: Hodder \& Stoughton Ltd.

Herbert F, Herbert B and Anderson K (2005) The Road to Dune. New York, NY: Tor Books and A Tom Doherty Associates Book.

Hitchcock AS and Chase A (1950) Manual of the Grasses of the United States. Washington, D.C.: U.S Department of Agriculture.

Hitchcock CL, Cronquist A, Ownbey M et al. (1969) Vascular Plants of the Pacific Northwest, vol. 1. Seattle: Washington University Press. 
Hodder I (2012) Entangled: An Archaeology of the Relationships Between Humans and Things. Malden, MA: Wiley-Blackwell.

IPCC (2014) Climate change 2014: Mitigation of climate change. Contribution of working III to the fifth assessment report of the intergovernmental panel on climate change. Cambridge and New York, NY: Cambridge University Press. Available at: https://www.ipcc.ch/site/assets/uploads/2018/02/ipcc_wg3_ ar5_frontmatter.pdf(accessed 11 January 2021).

Kaminsky GM, Ruggiero P, Buijsman MC et al. (2010) Historical evolution of the Columbia River littoral cell. Marine Geology 273: 96-126.

Komar PD (1997) The Pacific Northwest Coast: Living With the Shores of Oregon and Washington. Durham and London: Duke University Press.

Kratz V (2020) Frank Herbert's ecology and the science of soil conservation. NICHE Network, Canadian History and Environment. Available at: https://niche-canada.org/2020/04/24/frank-herberts-ecologyand-the-science-of-soil-conservation/ (accessed 1 May 2020).

Kunzru H (2015) Dune, 50 years on: How a science fiction novel changed the world. The Guardian, 3 July. Available at: https://www.theguardian.com/books/2015/jul/03/dune-50-years-on-science-fiction-novelworld (accessed 30 October 2019).

Lamb FH (1898) Sand-dune reclamation on the Pacific coast. The Forester 4: 141-142.

LeCain T (2017) The Matter of History: How Things Create the Past. New York, NY: Cambridge University Press.

LeCain TJ (2015) Against the Anthropocene: A neo-materialist perspective. International Journal for History Culture and Modernity 3: 1.

Le Guin UK (1975) The Dispossessed. New York, NY: Avon Books.

Martínez ML, Maun MA and Psuty N (2008a) The fragility and conservation of the world's coastal dunes: Geomorphological, ecological and socioeconomics perspectives. In: Martínez ML and Psuty N (eds) Coastal Dunes, Ecology and Conservation. Berlin-Heidelberg-New York, NY: Springer-Verlag, pp. 355-369.

Martínez ML, Psuty N and Lubke RA (2008b) A perspective on coastal dunes. In: Martínez ML and Psuty N (eds) Coastal Dunes, Ecology and Conservation. Berlin-Heidelberg-New York: Springer-Verlag, pp. 3-10.

Martínez ML and Psuty N (eds) (2008) Coastal dunes, ecology and conservation. Berlin-Heidelberg-New York: Springer-Verlag.

McKie R (2012) Rachel Carson and the legacy of Silent Spring, The Guardian, 7 May. Available at: https:// www.theguardian.com/science/2012/may/27/rachel-carson-silent-spring-anniversary (accessed 30 July 2021).

McLaughlin W and Brown R (1942) Controlling Coastal Sand Dunes in the Pacific Northwest. Washington, DC: US Department of Agriculture. Available at: https://naldc.nal.usda.gov/download/CAT92981355/ PDF (accessed 20 November 2019).

Mostow RS, Barreto F, Biel R et al. (2021) Discovery of a dune-building hybrid beachgrass (Ammophila arenaria $\times$ A. breviligulata) in the U.S. Pacific Northwest. Ecosphere 12(4): e03501.

Nordstrom K (2000) Beaches and Dunes of Developed Coasts. Cambridge: Cambridge University Press.

Nordstrom K (2008) Beach and Dune Restoration. Cambridge: Cambridge University Press.

Oregon Coastal Zone Management Association (1979) Beaches and Dunes Handbook for the Oregon Coast, vol. I. Newport. Available at: https://www.ci.florence.or.us/planning/beaches-and-dunes-handbook-oregon-coast (accessed 11 January 2021).

Oregon Dunes Restoration Collaborative (2018) Restoring the Oregon's dunes: The Bid to save a national treasure. Available at: https://www.saveoregondunes.org/wp-content/uploads/2018/02/Dunes-RestorationStrategy.pdf (accessed 29 July 2021).

Packham AJ and Willis JR (1997) Ecology of Dunes, Salt Marsh and Shingle. New York: Springer.

Pak C (2016) Ecology and Environmental Awareness in 1960s-1970s Terraforming Stories. Liverpool: Liverpool University Press.

Pearce F (2019) Geoengineer the planet? More scientists now say it must be an option. Yale Environment 360. Available at: https://e360.yale.edu/features/geoengineer-the-planet-more-scientists-now-say-it-must-bean-option (accessed 12 January 2021). 
Pinto C, Silovsky E, Henley F et al. (1972) Resource Inventory Report for the Oregon Dunes National Recreation Area Siuslaw National Forest. US Department of Agriculture. Available at: https://archive. org/details/CAT81757533/mode/2up (accessed 26 March 2020).

Public Law 92-260 (1972) Act to establish the Oregon Dunes National Recreation Area in the state of Oregon and for other purposes. Available at: https://www.govtrack.us/congress/bills/92/s1977/text (accessed 20 November 2019).

Rahman AA, Artaxo P, Asrat A et al. (2018) Developing countries must lead on solar geoengineering research. Nature 556: 22-24.

Reckendorf F, Leach D, Baum R et al. (1985) Stabilization of sand dunes in Oregon. Agricultural History 59: 260-268.

Ritson K (2019) The Shifting Sands of the North Sea Lowlands: Literary and Historical Imaginaries. London and New York, NY: Routledge.

Robbins W (1997) Landscapes of Promise: The Oregon Story 1800-1940. Seattle, WA and London: University of Washington Press.

Rome A (2003) 'Give earth a chance': The environmental movement and the sixties. Journal of American History 90: 525-554.

Ruggiero P, Kratzmann MG, Himmelstoss EA et al. (2012) National assessement of shoreline change: Historical shoreline change along the Pacific Northwest coast. US Geological Survey open-file report 2012-1007. Available at: https://pubs.er.usgs.gov/publication/ofr20121007 (accessed 12 November 2019).

Scholfield N (1854) The Siuslaw river. The Umpqua Weekly, 19 May.

Scott J (1998) Seeing Like a State: How Certain Schemes to Improve the Human Condition Have Failed. New Haven, CT and London: Yale University Press.

Skinner ML (1971) Florence, the 'Fir-Clad' city. Lane County Historical Society 16: 25-31.

Sture I (2012) The rise and fall of the Aizjomi landscape. Geography Review 102: 427-445.

Symons TW (1891) Yarrow Symons report, Eugene City Guard, 1 August.

Temple S (2011) Forestation and its discontents: The invention of an uncertain landscape in southwestern France, 1850-present. Environment and History 17: 13-34.

The Coos Bay Times (1913) Would reclamation coast lands, 22 January.

The Daily Journal (1902) Reclaim sand dunes, 25 July.

The Forester (1897) The Dunes and Landes of Gascogny, 7: 88-90.

The Morning Oregonian (1900) To bind shifting sands, 8 October.

The Morning Oregonian (1913) Ranger sets windbreak. Forester at florence to protect seeds for pine forest, 13 January.

The Sunday Oregonian (1912a) Bounty fields undeveloped in rich fields around thriving florence, 4 February. The Sunday Oregonian (1912b) Fish and game supply plentiful in vast Siuslaw National Reserve, 8 December. The Sunday Oregonian (1913) Clatsop move unusual, 12 January.

Thomas R (2010) Life in the Siuslaw valley prior to the European settlement. In: Whereat D (ed.) Our Culture and History: The Confederated Tribes of the Coos, Lower Umpqua and Siuslaw Indians, pp 14-17. Available at: https://shichils.files.wordpress.com/2017/10/our_culture_history.pdf (accessed 30 July 2021).

Tri-Weekly Astoria (1874) Sea ridge reclamation, 17 January.

Tsing AL (2015) The Mushroom at the End of the World: On the Possibility of Life in Capitalist Ruins. Princeton, NJ: Princeton University Press.

USDA Soil Conservation Service and the Oregon Coastal Conservation and Development Commission (1975) Beaches and Dunes of the Oregon Coast. Portland. Available at: https://ir.library.oregonstate. edu/concern/defaults/xp68km141 (accessed 18 November 2019).

Van Dam PJEM (2010) Rabbits swimming across borders: Micro-environmental infrastructures and macroenvironmental changes in early modern Holland. In: Bruce SG (ed.) Ecologies and Economies in Medieval and Early Modern Europe. Studies in Environmental History for Richard C. Hoffman. Leiden, Boston: Brill, pp. 63-91. 
Webb JA, Watts RJ et al. (2017) Principles for monitoring, evaluation, and adaptative management of environmental water regimes. In: Horne AC, Webb JA et al. (eds) Water for the Environment From Policy and Science to Implementation and Management. Cambridge: Elsevier, pp. 599-624.

Westgate JM (1904) Reclamation of the Cape Cod sand dunes. Bureau of Plant Industry - Bulletin 65.

Whereat D (2010) Our Culture and History. The Confederated Tribes of the Coos, Lower Umpqua and Siuslaw Indians. Available at: https://shichils.files.wordpress.com/2017/10/our_culture_history.pdf (accessed 30 July 2021).

White D (2018) Design, hybridity and just transitions. In: Radical Hope: Inspiring Sustainability Transformations Through our Past. Available at: https://radicalhopesyllabus.com/tag/damian-white/ (accessed 3 April 2020).

Wiedemann AM and Pickart AJ (2008) Temperate zone coastal dunes. In: Martínez ML and Psuty N (eds) Coastal Dunes, Ecology and Conservation. Berlin-Heidelberg-New York: Spinger-Verlag, pp. 53-65.

Worster D (2004) Dust Bowl: The Southern Plains in the 1930s. Oxford and New York, NY: Oxford University Press.

Zarnetske PL, Ruggiero P, Seabloom EW et al. (2015) Coastal foredune evolution: The relative influence of vegetation and sand supply in the US Pacific Northwest. Journal of The Royal Society Interface 12: 20150017. 